\title{
CENTENARY OF THE HUNGARIAN RED CROSS
}

On 18 May the Hungarian Red Cross celebrated the centenary of its foundation and International Review has the pleasure of publishing a summary of its history, written by the President of its Executive Committee, Mr. János Hantos.

International Review extends its congratulations and best wishes to the Hungarian Red Cross and its most sincere thanks to Mr. János Hantos for his contribution to this issue.

\section{FOUNDATION}

The accession, on 21 July 1866, of the Austro-Hungarian monarchy to the Geneva Convention of 1864 was an incentive to set up voluntary relief committees on Hungarian territory. It was therefore suggested that a relief organization should be set up, to which Hungary agreed, while insisting that the future organization should be autonomous and purely Hungarian.

The principle of unity, requiring only one Red Cross Society to operate in any one State, delayed the creation of the Hungarian Red Cross, for all the parties involved first had to reach an agreement on the form the future Society would take.

On 12 April 1878, Francis Joseph I, Emperor of Austria and King of Hungary, convened a conference in Vienna, which laid down the organizational and operational principles of a voluntary relief organization on Hungarian territory. One of these principles stipulates that "both parts of the Austro-Hungarian monarchy shall establish independently, according to their various laws and customs, an autonomous relief association and organize it on their own territory". On the basis of this principle the Hungarian Government, on 20 August 1879, authorized its Prime Minister to request the King's permission to create this association and on 5 December 1880, Francis Joseph I entrusted Count Gyula Károlyi, member of the High Chamber, with the duty of setting up the Hungarian Red Cross. 
The creation of this relief organization came at exactly the right time, for at the end of July 1878 the Austro-Hungarian army, composed mainly of Hungarian soldiers, had occupied Bosnia-Herzegovina, which had until then been under Turkish rule.

Ladies' Associations were already working in Budapest. They all gathered together in August 1878 and made a national collection to provide relief for combatants and wounded. On 27 March 1878 the Hungarian National Women's Relief Association was founded. The Minister for Foreign Affairs authorized it provisionally to use the Red Cross emblem and it may therefore be considered as the precursor of the Hungarian Red Cross.

\section{FIRST STEPS}

When the King had given his permission, a general assembly proclaimed, on 16 May 1881, the creation of the Red Cross Association of the Countries of the Holy Hungarian Crown. That same day the Hungarian National Women's Relief Association decided to join the Red Cross Association, which it duly did on 18 May 1881 at a joint assembly of both organizations. The Red Cross representatives of Croatia-Slovania announced their adherence to the Red Cross Association of the Countries of the Holy Hungarian Crown, while reserving their right to autonomy provided for under the statutes. The International Committee of the Red Cross recognized the Hungarian Red Cross Association on 20 January 1882.

The Association rapidly set to work. By organizing national collections and loteries it established a fund to finance its hospital building programme. It also organized teams for transporting the wounded and mobile supply depots for ambulances. A nurse training programme was launched and on 19 October 1884 the first hospital was opened. To begin with the work of the Hungarian Red Cross mainly consisted in providing relief to victims of disasters and taking part in the anti-epidemic campaigns in different areas of the country. The Hungarian Association thus gradually developed and its organization became increasingly efficient. Before the end of the century committees had been set up in all the comitats.

The Third International Red Cross Conference, which was held in Geneva in 1884, gave the Hungarian Red Cross an opportunity of participating for the first time in the work of the supreme body of the international movement. In 1885, during the Serbo-Bulgarian war, it undertook its first international relief operation. It was on Hungary's 
proposal at the Eighth International Red Cross Conference in London in 1907 that the Florence Nightingale medal was created as a special distinction for nurses.

\section{DIFFICULT TIMES}

The Hungarian Red Cross was severely tried during the First World War. On the first day of mobilization it placed 9 hospitals, 507 auxiliary hospitals, 517 dressing posts and 44 field hospitals-a total of 50,582 beds-at the high command's disposal. Special six-week courses were organized to speed up the training of voluntary nurses. To supplement military medical services the Red Cross sent mobile teams of surgeons on the battlefields. An information bureau on combatants wounded or killed in action and an assistance and information bureau for prisoners of war were set up. Collections were organized throughout the country to raise the necessary funds for all those activities.

The losses suffered during the war gave rise to extreme tension in the country, which led to the revolutions of 1918-1919. The Government of independent Hungary, separated from the monarchy, appointed the wife the President of the Republic, Mrs Károlyi, President of the Red Cross. The Government of the new Hungarian Republic appreciated the role of the Red Cross and counted upon its help. The People's Commissariat for Social Welfare and Public Health stipulated in an order of 1919 that "all, and especially the political and military authorities, have the obligation to afford efficient help to the Red Cross, in conformity with its neutrality, and to support it in its functions".

Soon after, however, was a lull in the activity of the organization, as is shown by Red Cross President Count Emil Széchenyi's address to the first general assembly following the war, in 1924. There had nevertheless been two major achievements, i.e. the creation of the Junior Red Cross on 9 February 1921, on the initiative and with the support of the League, and the resumption of the nurse training programme in 1923. Throughout those post-war years the country struggled against grave social and economic problems: unemployment and poverty had reached alarming proportions and the Red Cross launched several operations and campaigns to help the poor.

In the 1930's Red Cross activities developed considerably. On a proposal by the Fourteenth International Red Cross Conference (Brussels, 1930) a service to provide first aid on the roads was created. An international conference of first aid and road accident prevention experts was organized in Budapest from 20 to 24 May 1935, with co-operation from the League and other international organizations. 
During the latter half of the 1930's the Hungarian Red Cross began instructing the civilian population in civil defence and preparing itself for its various duties in the event of war.

The statutes were amended in 1940 and stipulated that in case of war the Red Cross would function as an auxiliary to the army medical services. When Hungary entered the war the National Society provided the armed forces command with military hospitals, hospital trains and specialized staff.

From the beginning of the Second World War, from 10 September 1939 already, the Hungarian Red Cross took on the major task of assisting Polish refugees flowing into Hungary. With the help of the International Committee of the Red Cross, it ran 82 military and civilian refugee camps and contributed to their maintenance. According to the reports published in the Bulletin international de la Croix-Rouge ${ }^{1}$ 30,681 Polish soldiers and 11,000 civilian Polish refugees were assisted by the Hungarian Red Cross up to March 1940. Assistance to Polish refugees naturally continued after that and the Society also affered its services to refugees from other countries. From the spring of 1940, several hundred French people and, after 1942, many Soviet prisoners of war who had fled German internment camps found refuge in camps set up by the Hungarian Red Cross. Its relief bureau provided help for Belgian and then Italian prisoners of war and it sent food parcels to Belgian and Dutch children. A sad episode in Hungarian history began on 15 October 1944, when the German troops occupied the country, making the humanitarian action of the Hungarian Red Cross almost impossible for some time.

\section{NEW POSSIBILITIES - NEW TASKS}

The Soviet troops entered Hungary in the autumn of 1944 and freed the country from German occupation. It had suffered considerably during the war and recovered slowly. The Hungarian Provisional Government appointed a director at the head of the Hungarian Red Cross and gave him the duty of reorganizing the National Society even before the country was fully liberated.

One of the Society's first tasks was to repatriate Hungarians who had been deported or had fled the country. It opened offices in Austria and Germany for this purpose and, with the help of the ICRC, 330,000 Hun-

${ }^{1}$ Published by the ICRC as a supplement to Revue internationale de la CroixRouge. 
garians, former prisoners of war, deportees or civilian refugees, were thus repatriated from 1944 to 1947. In Hungary itself, the National Society was caring for repatriated prisoners of war, running a tracing sevice for missing persons, protecting children who had lost contact with their families and contributing to solving the country's social problems.

In the course of the next few years, as external conditions improved, the tasks of the Red Cross changed. A national conference of the Hungarian Red Cross, held on 14 and 15 April 1951, laid down the following main duties: hygiene education, recruitment of blood donors, teaching and organization of first aid.

On 3 August 1954, the Presidential Council of the Hungarian People's Republic ratified the Geneva Conventions of 1949. In 1955, it issued an Order in Council concerning the National Red Cross, in which the Society is described as a democratic mass organization whose "mission, in peace-time, is to contribute towards improving the health of the people and, in war-time, to discharge its duties in protecting victims of war, in application of the Geneva Conventions".

During the events of 1956, which caused chaos throughout the country, the Hungarian Red Cross worked unter extremely difficult conditions: law and order were no longer respected, supplies became impossible and the population suffered from hunger and cold. The first plane-load of relief arrived from Poland, then the ICRC organized an airlift between Vienna and Budapest. An ICRC delegation remained in Hungary until the end of September 1957 and worked very hard distributing food, fuel, medical equipment, pharmaceutical products and other forms of relief.

The improvement of the situation within the country enabled a temporary national Bureau to assume the direction of the Hungarian Red Cross, headed by Academician Paul Gegesi-Kiss.

\section{THE HUNGARIAN RED CROSS, A MASS ORGANIZATION}

Since then, the Hungarian Red Cross has had an increasingly active share in solving the country's health and social problems and it has gradually developed into a mass organization. The first major step in this direction was its first congress, convened in 1959. This congress was followed by five others, which all expressed their appreciation of the way in which the National Society had developed and which laid down its most important tasks and duties.

The Hungarian Red Cross now numbers over one million members, gathered in 13,000 basic sections, whose spheres of activity are the work- 
place, home or school. It is thanks to these voluntary members and their dedication that the ideas and programmes of the Red Cross can be carried out. Their work is extremely varied: they try and improve the population's knowledge of hygiene, provide social care, home care and care for the elderly, organize blood collections, teach first aid and take turns on duty in first aid posts. They contribute to the protection of the family, children and youth, and the environment; they provide social assistance for the uneducated parts of the population, for the disabled and elderly persons. They form first aid sections in the civil defence organization and provide nurses and volunteers who are always ready to take part in relief operations in the event of disaster. They are also active in disseminating the principles and ideals of the Red Cross and the elements of international humanitarian law.

The Hungarian Red Cross takes an increasingly active part in international relief operations organized during armed conflicts or in the event of natural disasters, while supporting the development programme of the League.

On the eve of its second century of existence, the gratefulness and the confidence the Hungarian population feels for its National Red Cross stimulate its leaders and members to face future responsibilities and duties with courage and determination.

\section{János Hantos}

President of the Executive Committee of the Hungarian Red Cross 